\title{
Study of Platelet Volume and Platelet Count Changes during Pregnancy as a Marker for Prediction of Preterm Premature Rupture of Membrane
}

\author{
SAFAA A. IBRAHIM, M.D. and AHMED M. FARAG, M.D. \\ The Department of Obstetrics and Gynecology, Faculty of Medicine, Zagazig University, Egypt
}

\begin{abstract}
Aim: To investigate the level of platelet volume and number precede Preterm Premature Rupture of Membrane (PPROM) development and to determine the predictive value of these markers for prediction of PPROM.

Methods: A total of 979 pregnant women who received regular antenatal care until delivery were included. Participants were divided into 2 groups: Pregnant women with PPROM $(\mathrm{n}=140)$, and women without PPROM $(\mathrm{n}=839)$. Blood samples were collected during antenatal visits and/or during the period of inpatient hospital stay and changes in Mean Platelet Volume (MPV) and Platelet Count (PC) were compared between the two groups.

Results: Compared with controls, women with PPROM had significantly increased levels of PC and significantly decreased levels of MPV in the first trimester $(p<0.001)$. The area under the receiver operator curve was 0.9 for MPV and 0.67 for PC. The cut-off values of MPV $<-7.9 \mathrm{fL}$ and PC $>! 270$ $\mathrm{X} 10^{3} / \mu 1$ predicted PPROM with a sensitivity of $69 \%$ and $70 \%$ and specificity of $58 \%$ and $50 \%$, respectively.

Conclusion: MPV can be used as a more efficient predictor for an early diagnosis of PPROM in the first trimester between 12 and 14 weeks' gestation than PC. However, further research combining other markers is needed to increase the efficiency of prediction.
\end{abstract}

Key Words: Blood platelet count - Mean platelet volume Preterm premature rupture of the membranes Serum markers.

\section{Introduction}

PREMATURE rupture of the membranes (PROM) is rupture of fetal membranes before onset of labor. If it occurs before 37 weeks' gestation, it is called preterm premature rupture of membrane (PPROM). It occurs in approximately 2-3\% of all pregnancies and is the leading identifiable cause of preterm delivery [1]. Some of the possible causes of PPROM

Correspondence to: Dr. Safaa A. Ibrahim, The Department of Obstetrics and Gynecology, Faculty of Medicine, Zagazig University, Egypt are an intra-amniotic infection, smoking, multiple pregnancies, nutritional deficiencies, antepartum hemorrhage, polyhydramnios and cervical incompetence [2,3]. Chronic infection of fetal membranes has a clear role in the initiation and propagation of molecular events leading to PPROM [4].

Previous studies have identified that intrauterine infection triggers an increase of several cytokines in maternal serum as well as amniotic fluid [5-7] As inflammatory markers are in close relation with cytokines, we hypothesize that PPROM may be associated with alteration of these markers in maternal serum in the first trimester. Both CReactive Protein (CRP) and leukocyte levels were shown to be increased in serum of patients preceding PPROM [8,9]. Platelet Count (PC) and Mean Platelet Volume (MPV) constitute part of the data detectable by Complete Blood Count (CBC) test. The applicability of these indices for the clinical and pathophysiological understanding of several diseases, as in PPROM has not been investigated. Platelet activation has been noticed in the pathophysiology of infection, inflammation, and malignancy [10]. The MPV is a reliable indicator of platelet size that reflects platelet function and activation. Previous studies reported the association of MPV with both pro-thrombosis and proinflammation [10]. The aim of this observational study was to investigate the diagnostic performance of platelet volume and number changes during pregnancy for prediction of PPROM.

\section{Subjects and Methods}

Study design:

This was an observational longitudinal study of women Attending Antenatal Clinic (ANC) and/or admitted to the maternity ward at our hospital during period from June 2016 to June 2017. The 
study protocol was approved by Zagazig University Ethical Committee. A clear explanation of the study protocol was given for participating women, and a written informed consent was then obtained from all of them.

Inclusion criteria: Healthy pregnant women at $\geq 6$ weeks' gestation with a live singleton fetus were eligible for recruitment.

Exclusion criteria: Women with the following conditions were ineligible and excluded: Multiple pregnancy, morbid obesity with Body Mass Index (BMI) $\geq 40 \mathrm{Kg} / \mathrm{m}^{2}$, poor past obstetric history (PTL (Pre-Term Labor), IUGR (Intrauterine Growth Restriction) [estimated fetal weight $<10$ th percentile for gestational age], invasive prenatal diagnostic procedures, cervical surgery, prior preterm labor, PPROM or currently suffering from a systemic disease (hypertension, gestational or insulindependent diabetes, heart disease, renal or hepatic dysfunction).

\section{Study protocol:}

During the enrolment of ANC visit at $\geq 6$ weeks' gestation, past, medical, surgical and obstetric history was reviewed. General and abdominal examinations were carried out, fetal heart rate was checked and findings were recorded. Routine investigations including CBC were arranged. In women with prior regular periods, gestational age was estimated from the date of last menstrual period. Otherwise, gestational age was estimated from early ultrasound scan (USS) at 7 weeks' gestation. Gestational age was verified by the 13 th week USS. Fetal anomaly USS was arranged at around 20 weeks' gestation. Women were then reviewed as per the routine antenatal clinic protocol where they attended every 4 weeks until 28 weeks' gestation, every 2 weeks until 36 weeks' gestation then weekly thereafter until delivery. Those who developed PPROM were admitted, a blood sample for CBC was taken at each clinic visit, PPROM diagnosis is confirmed by the presence of pooling of amniotic fluid in the vagina by sterile speculum examination. Using EDTA samples tubes $(5 \mathrm{ml})$; venous blood samples were drawn from all participants. Samples were processed within two hours after venipuncture. Automated blood counter CellDyn 4000 (Abbott Diagnostics, Santa Clara, CA, USA) was used after calibration to assess CBC parameters including platelet indices ( $\mathrm{PC}$ and MPV). The primary outcome was to determine the correlation if any, between changes in selected platelet indices during pregnancy on one hand and occurrence of PPROM on the other hand.
Ethical approval: Informed consent was taken from each patient. The research protocol was approved by the Ethical Committee of Zagazig University Hospitals.

\section{Statistical analysis:}

The data are presented as the mean \pm Standard Deviation (SD) and were processed and analysed using SPSS version 20 (Statistics for Windows, IBM Corp, Armonk, NY, USA). We determined the statistical significance between the two groups using one-way ANOVA (analysis of variance) supplemented with the post hoc LSD test. We compared paired quantitative continuous data using a paired $t$-test. Receiver Operating Characteristic (ROC) curve analysis was used to reveal the cutoff values, Areas Under the Curve (AUCs) and 95\% Confidence Intervals (CIs) for PC and MPV. A $p$-value of $\leq 0.05$ was deemed to indicate statistical significance.

\section{Results}

We summarized the demographic and baseline characteristics for all participants in (Table 1). Both groups were parallel in all features registered except for gestational age at delivery, which is expected finding in PPROM.

Table (2) showed comparisons between changes in PC, MPV and in both study groups. With the exception of few patients in the PPROM group, participants in all groups had a normal PC, but showed a continuous increase throughout pregnancy starting from 12-14 weeks' gestation onwards. Compared with the baseline values, MPV in PPROM group showed a continuous decrease throughout pregnancy starting from 12-14 weeks' gestation onwards. These changes preceded the occurrence of PPROM by 8-20 weeks despite significantly higher MPV and lower PC in the first trimester than the control group $(p<0.001)$.

ROC analysis revealed an AUC of 0.09 (95\% CI $0.12-0.05, p<0.001$ ) for MPV and an AUC of 0.67 (95\% CI 0.6-0.7, $p<0.001$ ) for PC. The best cut-off value with optimal sensitivity and specificity for MPV was $\leq 7.9 \mathrm{fL}$. The application of this cutoff value predicted PPROM with a sensitivity of $69 \%$, a specificity of 58\%, a Positive Predictive Value (PPV) of $62.5 \%$, a Negative Predictive Value (NPV) of $65.6 \%$, and an accuracy of $64 \%$. The best cut-off value with optimal şensitivity and specificity for PC was $\geq 270 \times 10 \%$ The application of this cut-off value predicted PPROM with a sensitivity of 70 , a specificity of $50 \%$, a PPV of $64.9 \%$, a NPV of $67.4 \%$, and an accuracy of $66 \%$ (Table 3). 
Table (1): Socio-demographic characteristics of both groups.

\begin{tabular}{|c|c|c|c|c|}
\hline Variable & $\begin{array}{l}\text { Group I } \\
\text { PPROM } \\
(n=140)\end{array}$ & $\begin{array}{c}\text { Group II } \\
\text { without PPROM } \\
(\mathrm{n}=839)\end{array}$ & $\begin{array}{c}t- \\
\text { test }\end{array}$ & $p$ \\
\hline $\begin{array}{l}\text { Maternal age (years): } \\
\text { Mean } \pm \text { SD } \\
\text { Range }\end{array}$ & $\begin{array}{l}26.1 \pm 4.3 \\
20-34\end{array}$ & $\begin{array}{l}26.4 \pm 4.2 \\
19-34\end{array}$ & 0.3 & 0.7 \\
\hline $\begin{array}{l}\text { GA at delivery (weeks): } \\
\text { Mean } \pm \text { SD } \\
\text { Range }\end{array}$ & $\begin{array}{l}28.4 \pm 0.7 \\
17-35\end{array}$ & $\begin{array}{l}38.4 \pm 0.7 \\
37-39\end{array}$ & 0.3 & $0.001 *$ \\
\hline $\begin{array}{l}\text { BMI: } \\
\quad \text { Mean } \pm \mathrm{SD} \\
\text { Range } \\
\text { History of previous }\end{array}$ & $\begin{array}{l}26.2 \pm 2.5 \\
20.6-30\end{array}$ & $\begin{array}{l}25.9 \pm 2.2 \\
21-30\end{array}$ & 0.4 & 0.7 \\
\hline $\begin{array}{l}\text { Abortions: } \\
\quad \text { Mean } \pm \text { SD } \\
\text { Range }\end{array}$ & $\begin{array}{l}43.1 \pm 9.4 \\
25-60\end{array}$ & $\begin{array}{l}38.4 \pm 7.5 \\
25-60\end{array}$ & 0.4 & 0.7 \\
\hline $\begin{array}{l}\text { Gravidity: } \\
\quad \text { Mean } \pm \text { SD } \\
\text { Range }\end{array}$ & $\begin{array}{l}2.5 \pm 1.1 \\
1-5\end{array}$ & $\begin{array}{l}2.4 \pm 1.2 \\
1-5\end{array}$ & 0.2 & 0.8 \\
\hline $\begin{array}{l}\text { Parity: } \\
\quad \text { Mean } \pm \text { SD } \\
\quad \text { Range }\end{array}$ & $\begin{array}{l}1.3 \pm 0.7 \\
0-2\end{array}$ & $\begin{array}{l}1.2 \pm 0.5 \\
0-3\end{array}$ & 0.6 & 0.5 \\
\hline
\end{tabular}

PPROM : Preterm Premature Rupture of Membrane.

SD : Standard Deviation.

BMI : Body Mass Index.

GA : Gestational Age.

$* \quad:$ Statistically significant difference $(p \leq 0.05)$.

$* * \quad$ : Statistically high significant difference $(p \leq 0.001)$.

Table (2): PC and MPV in both studied groups.

\begin{tabular}{|c|c|c|c|c|c|}
\hline Variable & $\begin{array}{c}\text { Gestational } \\
\text { age } \\
\text { (weeks) }\end{array}$ & $\begin{array}{l}\text { Group I } \\
\text { PPROM } \\
(n=140)\end{array}$ & $\begin{array}{l}\text { Group II } \\
\text { without } \\
\text { PPROM } \\
(\mathrm{n}=839)\end{array}$ & $\begin{array}{c}t- \\
\text { test }\end{array}$ & $p$ \\
\hline \multirow[t]{2}{*}{$\begin{array}{l}\cdot \mathrm{PC} \\
\left(\mathrm{X} 10^{3} / \mathrm{mm}^{3}\right)\end{array}$} & $\begin{array}{l}\text { - } 12-14 \text { (onset of } \\
\text { change) }\end{array}$ & $262 \pm 55$ & $240.6 \pm 43$ & 7.8 & 0.001 \\
\hline & $\begin{array}{l}\text { 24-35 (onset of } \\
\text { diagnosis) }\end{array}$ & $270 \pm 65$ & $245.2 \pm 45$ & 4.9 & 0.001 \\
\hline \multirow[t]{2}{*}{ • MPV (fL) } & $\begin{array}{l}\text { - } 12-14 \text { (onset of } \\
\text { change) }\end{array}$ & $9.9 \pm 1.7$ & $8.7 \pm 1.5$ & 5.3 & 0.001 \\
\hline & $\begin{array}{l}\text { 24-35 (onset of } \\
\text { diagnosis) }\end{array}$ & $8.8 \pm 1.3$ & $10.2 \pm 1.1$ & 9.5 & 0.001 \\
\hline
\end{tabular}

Data are represented as mean $\pm \mathrm{SD}$.

PPROM : Preterm Premature Rupture of Membrane.

PC : Platelet Count.

MPV : Mean Platelet Volume.

SD : Standard Deviation

Table (3): Diagnostic performance of PC and MPV for prediction of PPROM.

\begin{tabular}{lll}
\hline & PC (X 103/mm3) & MPV (fL) \\
\hline Accuracy (\%) & 66 & 64 \\
Sensitivity (\%) & 70 & 69 \\
Specificity (\%) & 50 & 58 \\
PPV (\%) & 64.9 & 62.5 \\
NPV (\%) & 67.4 & 65.6 \\
AUC (95\% CI) & $0.67(0.6-0.7)$ & $0.09(0.12-0.05)$ \\
Cut-off & 270 & 7.9 \\
$p$-value & 0.001 & 0.001 \\
\hline
\end{tabular}

PPROM : Preterm Premature Rupture of Membrane.

PC : Platelet Count. NPN : Negative Predictive Value.

MPV: Mean Platelet Volume. AUC: Area Under Curve.

PPV : Positive Predictive Value. CI : Confidence Interval.

\section{Discussion}

Our study indicated that PC was significantly increased and MPV was significantly decreased from 12 to 14 weeks' gestation onwards, and these changes preceded the occurrence of PPROM by 8 to 20 weeks. Early prediction of a patient who may be prone to PPROM, could provide prophylactic measures for these patients.

The risk factors for PPROM were mostly based on maternal characteristics and past obstetric history, such as history of PTL or PPROM are the most suggestive risk factor [11]. However, no risk factors can be identified in most patients. Reactive thrombocytosis that occurs early in cases of PPROM is a form of thrombocytosis that occurs secondary to medical or surgical conditions [10], can explain early MPV decrement with a high PC in the prediction of PPROM. During normal pregnancy, it was suggested that platelet function is evaluated more by changes in MPV rather than PC [12]. Decreased MPV may be related to several chronic inflammations such as inflammatory bowel disease. It plays a role as a marker not only for inflammation but also for prognosis and follows up of anti-inflammatory treatment [10]. The most common cause of PPROM among the involved multiple mechanisms is intrauterine inflammation [4], which is mostly subclinical in nature [13]. In cases of intra-amniotic infection, cytokines are produced within the uterine cavity and then they reach the maternal circulation. Overproduction of cytokines, such as interleukin IL-4, IL-6 and tumor necrosis factor, influence platelet characteristics by interfering with megakaryopoiesis and subsequent release of predominantly small platelets from the bone marrow [10]. It is important to note that infection or inflammation at sites distant from female genital tract may also contribute to the occurrence of PPROM due to increase level of circulating pro-inflammatory cytokines and potentially small platelet [14]. Ekin et al., [15] have found that patients who develop PPROM showed significantly lower MPV and higher PC in the first trimester than control group.

Our study showed that MPV is superior to PC as predictive factor in patients with PPROM with a cut-off value for MPV was $\leq 7.9 \mathrm{fL}$ and for PC was $\geq 270 \times 10 \%$ The sensitivity, specificity, PPV and NPV of MPV were $68 \%, 58 \%, 62.5 \%$ and $65.5 \%$, respectively, with AUC (0.09), 95\% CI (0.05-0.12). The sensitivity, specificity, PPV and NPV of PC were $70 \%, 50 \%, 64.9 \%$ and $67.4 \%$, respectively, with AUC (0.67), 95\% CI (0.6-0.7). Ekin et al., [15] revealed that an AUC (0.642), 95\% 
CI (0.601-0.683) and $p<0.001$ for PC and AUC (0.579), 95\% CI (0.536-0.622) and $p<0.001$ for MPV, indicating that MPV was superior to PC as a predictor for PPROM with a cut-off value for MPV was $<8.6 \mathrm{fL}$ and for PC >216 X $10^{3} / \mathrm{g} 1$ with a sensitivity of $62 \%$ \& $44 \%$, PPV of $56 \%$ \& $49 \%$ and NPV of $64 \% \& 60 \%$, however this study was retrospective. Also, Myatt et al., [16] stated that the association of MPV identified susceptible women with subclinical vascular dysfunction. In another study, Gioia et al., reported that MPV $\geq 1$ 0fL may be associated with adverse neonatal outcomes in women affected by abnormal uterine artery Doppler findings [17].

The results of the present study are similar to the studies regarding other markers of inflammation. A number of studies found that pregnant women with high CRP levels during the first half of pregnancy are at risk of later development of PPROM $[8,18]$.

Tzur et al., [9] investigated maternal leukocyte count in the first trimester of pregnancy and the risk for development of obstetric complications. They found a significant association between leukocytosis during the first trimester and PPROM. According to these reports, it is evident that there is a strong relevance between levels of inflammation markers and occurrence of PPROM because of regulated secretion by cytokines.

The strength of this study was that all blood samples for CBC assessment were processed within two hours after venipuncture. The assessments were performed using the same anticoagulant and the same automated counter. A large number of recruited participants, as well as enrollment of women early and throughout pregnancy, give further credit to our conclusion.

\section{Conclusion:}

We found that MPV could be used as a more efficient indicator for an early diagnosis of PPROM than platelet count. Thus, our study can serve as a reference data for clinical practice in detecting those asymptomatic women with subclinical intraamniotic infection at increased risk for PPROM and subsequent preterm delivery. The MPV is a cheap, rapid and easily applicable test for determining the patients at risk for PPROM. Due to the multifactorial origin of PPROM, early detection of all patients with a single test is rather difficult in order to develop an accurate and efficient method.

Funding: The authors state that this work has not received any funding.
Areas of conflict: The authors have no conflicts of interest relevant to this article.

\section{References}

1- SIMHAN H.N. and CANAVAN T.P.: Preterm premature rupture of membranes: Diagnosis, evaluation and management strategies. B.J.O.G., 112: 32-37, 2005.

2- MERCER B.M.: Preterm premature rupture of membranes. Obstet. Gynecol., 101: 178-93, 2003.

3- PARRY S. and STRAUSS J.F.: Premature rupture of the fetal membranes. N. Engl. J. Med., 338: 663-70, 1998.

4- AAGAARD-TILLERY K.M., NUTHALAPATY F.S., RAMSEY P.S. and RAMIN K.D.: Preterm premature rupture of membranes: Perspectives surrounding controversies in management. Am. J. Perinatol., 22: 287-97, 2005.

5- ROMERO R., YOON B.H., MAZUR M., et al.: A comparative study of the diagnostic performance of amniotic fluid glucose, white blood cell count, interleukin-6, and gram stain in the detection of microbial invasion in patients with preterm premature rupture of membranes. Am. J. Obstet. Gynecol., 169: 839-51, 1993.

6- SANTHANAM U., AVILA C., ROMERO R., et al.: Cytokines in normal and abnormal parturition: Elevated amniotic fluid interleukin-6 levels in women with premature rupture of membranes associated with intrauterine infection. Cytokine, 3: 155-63, 1991.

7- MURTHA A.P., GREIG P.C., JIMMERSON C.E., ROITMAN-JOHNSON B., ALLEN J. and HERBERT W.N.: Maternal serum interleukin- 6 concentrations in patients with preterm premature rupture of membranes and evidence of infection. Am. J. Obstet. Gynecol., 175: 966-9, 1996.

8- MOGHADDAM BANAEM L., MOHAMADI B., ASGHARI JAAFARABADI M. and ALIYAN MOGHADAM N.: Maternal serum C-reactive protein in early pregnancy and occurrence of preterm premature rupture of membranes and preterm birth. J. Obstet. Gynecol. Res., 38: 780-6, 2012.

9- TZUR T., WEINTRAUB A.Y., SERGIENKO R. and SHEINER E.: Can leukocyte count during the first trimester of pregnancy predict later gestational complications? Arch. Gynecol. Obstet., 287: 421-7, 2013.

10- GASPARYAN A.Y., AYVAZYAN L., MIKHAILIDIS D.P. and KITAS G.D.: Mean platelet volume: A link between thrombosis and inflammation. Curr. Pharm. Des., 17: 47-58, 2011.

11- MERCER B.M., GOLDENBERG R.L., MEIS P.J., et al.: The Preterm Prediction Study: Prediction of preterm premature rupture of membranes through clinical findings and ancillary testing. The National Institute of Child Health and Human Development Maternal-Fetal Medicine Units Network. Am. J. Obstet. Gynecol., 183: 738-45, 2000.

12- TYGART S.G., Mc ROYAN D.K., SPINNAto J.A., et al.: Longitudinal study of platelet indices during normal pregnancy. Am. J. Obstet. Gynecol., 154: 883-7, 1986.

13- ROMERO R. and MAZOR M.: Infection and preterm labor. Clin. Obstet. Gynecol., 31: 553-84, 1988. 
14- OFFENBACHER S., BOGGESS K.A., MURTHA A.P. et al.: Progressive periodontal disease and risk of very preterm delivery. Obstet. Gynecol., 07: 29-36, 2006.

15- EKIN A., GEZER C., KULHAN G., AVCI M.E., et al.: Can platelet count and mean platelet volume during trimester of pregnancy predict premature rupture of membrane. J. Obstet. Gynaecol. Res., 41: 23-8, 2015.

16- MYATT L., CLIFTON R.G., ROBERTS J.M., et al.: First-trimester prediction of preeclampsia in low-risk nulliparous women. Obstetrics and Gynecology, 119 1234, 2012

17- GIOIA S., PIAZZE J., ANCESCHI M.M., et al.: Mean platelet volume: Association with adverse neonatal outcome. Platelets, 18: 284-8, 2007.

18- PITIPHAT W., GILLMAN M.W., JOSHIPURA K.J., et al.: Plasma C-reactive protein in early pregnancy and preterm delivery. Am. J. Epidemiol., 162: 1108-13, 2005.

\section{دراسة حجم الصفائح الد موية والتغيرات فى عددها أثناء الحمل الحماء

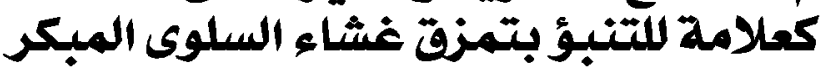

الهدف: دراسة التغير في مستقى حجم الصفائح الدهوية وعددها الذى يسبق حالات (PPROM) التمزق المبكر لغشاء العلوى وتحديد القيمة التنبؤية لهذه العلامات للمساعدة في التنبؤ بـPPROM.

طرق الدراسة: تم إدراج عدد ولو سيدة حامل تلقين رعاية طبية منتظمة من الحجم حتي الولادة. تم تقسيم المشاركين إلى مجموعتين:

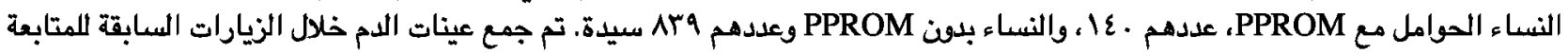

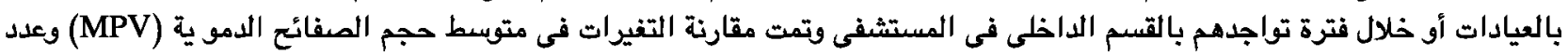
الصفائح الدموية (PC) بين المجموعتين.

النتائج: بالمقارنة مع الضوابط، زاد في النساء ذوات PPROM بشكل كبير عدد الصفائح الدموية وانخفض متوسط المجب بشكل كبير

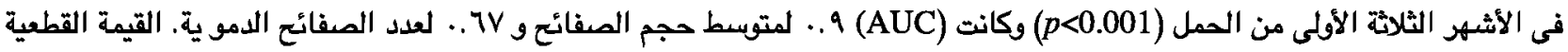

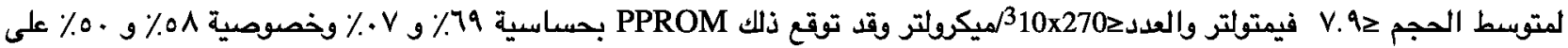
التوالى.

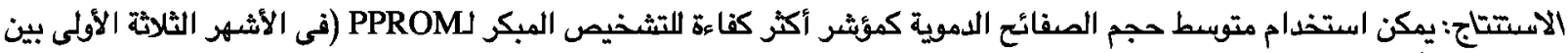

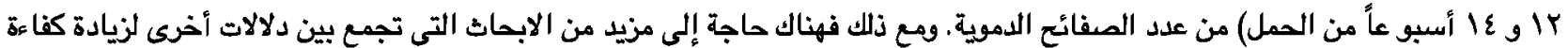

